\title{
Vocational School Alignment Based-on Industry Needs
}

\author{
Fitri Nur Mahmudah*, Budi Santosa \\ Email : fitri.mahmudah@mp.uad.ac.id * \\ *: coresponndensing author \\ Universitas Ahmad Dahlan, Jl. Pramuka No. 42, Pandeyan, Umbulharjo, Yogyakarta, Indonesia;
}

Article history

Received Feb 02, 2021

Revised May 21, 2021

Accepted May 31, 2021

Keywords

Aligment

Vocational School

Industry
Industrial development has an impact on competency requirements that must be aligned with the provision of competencies in vocational school. Vocational school graduates who are able to work in accordance with their field of expertise are one of the keys to the success of vocational education. The purpose of writing this article is to determine the vocational alignment based on the schema. The method used is qualitative with a case study approach. Data collection techniques using interviews. The research was conducted during a workshop organized by the Directorate of Vocational Education. The research subjects were Indonesian vocational school teachers. The research procedure used the Denzin \& Lincoln model. Data analysis was carried out with the assistance of the Atlas. ti software version 8.3. The results of this study provide information that there are three important things that need to be done by vocational school and Industry to be able to carry out and develop competencies, namely process, strategic management, and duties and responsibilities. The three things that are the findings, of course, have their respective indicators which can be done specifically by vocational school and Industry. The results of this research can be used as a collective reflection for vocational school and industry in increasing competence and developing the ability to create quality graduates for vocational school and to find competent workforce candidates for Industry.

This is an open access article under the CC-BY-SA license.

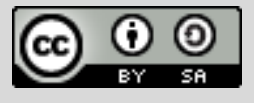

\section{Introduction}

The development of the era resulted in industrial development. This has an impact on the competencies needed in a growing industry. Vocational high schools that have and provide human resources as potential workers need to understand the context of this development. This is as stated by (OECD, 2020) that skilled population is not enough to achieve high and inclusive growth, as skills need to be put into productive use at work. The skills and competencies needed in the industry are not only knowing how but also how the workforce can maximize knowledge to be more productive in the industry. Things like this are the role of Vocational High Schools to ensure graduates have the skills and competencies needed by the industry. According to (OECD, 2020) that the workforce in professional training institutions benefit from a strong blend of pedagogical 
skills, industry experience and academic knowledge. The importance of knowledge and experience is a distinct advantage for both graduates and industry in the current development era. This alignment needs to be improved to anticipate the gap between vocational education and the demands and needs of the Industry. It's just that Indonesia still needs to improve the harmony between SMK and industry to solve problems and become solutions. Data from the Central Statistics Agency for the last two years, graduates at the Vocational High School level still occupy the highest percentage compared to other levels who are not absorbed in the industry. This is a form of mutual concern to overcome existing problems.

The data in Figure 1 above can be interpreted as that in February 2019 SMK graduates had a percentage of $8.63 \%$ who became the highest unemployed compared to other levels. In February 2020 , the percentage of unemployment generated by SMK graduates was reduced to $8.94 \%$. The low percentage of open unemployment at the SMK level is both happy news and a concern. Even though it is decreasing, in reality the percentage of SMK graduates is still the highest unemployed in Indonesia compared to graduates at other levels. This is the basis for following up existing practices in Vocational High Schools with industries that are still not suitable or relevant. This condition needs to be improved, especially in vocational alignment. So that SMK has the ideal conditions that are expected and needed by the industry. Therefore it is necessary to have intense communication between SMK and industry in managing two different roles.

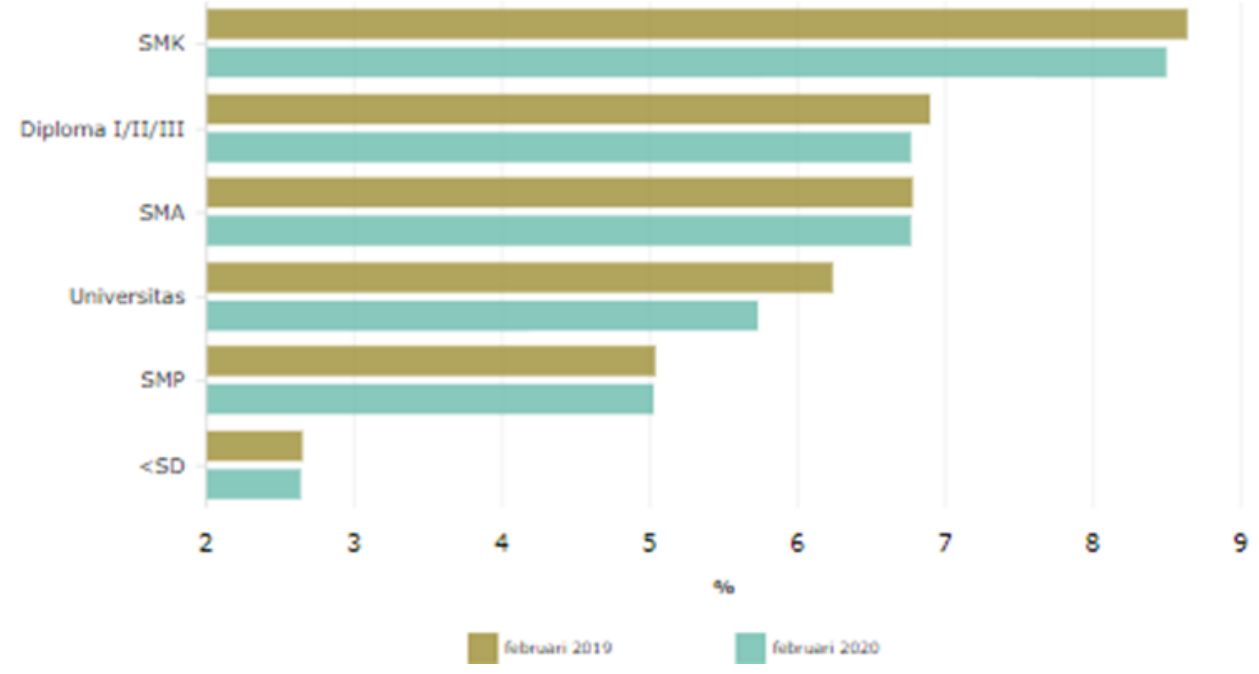

Figure 1. Unemployment Data in Indonesia

Vocational alignment is one of the activities that need to be jointly improved by SMK with Industry. This alignment becomes a vehicle for SMKs to improve and develop themselves. Both in terms of increasingly qualified and professional teachers, principals who have the capacity and industry mindset, and students who have the skills and competencies desired by the industry. This important role is like the results of research that has been done by (Rahayu, Wibowo, \& Sulastri, 2020 ) that one that is competitive and skilled is one that can be produced from quality vocational 
education that is relevant to the demands of a dynamic workforce. The same statement was also made by (Tamrin, Slamet, \& Soenarto, 2018) in research that has been done that the pattern of fulfillment of productive vocational school teachers carried out by center and local governments and found out the overview of link and match pattern of supply and demand for productive vocational school teachers with regards to vocational skills training programs in the perspective of educa- tion decentralization. Therefore, one of the programs that need to be designed by SMK is industrial class (Priambudi, Mahmudah, \& Susatya, 2020). Of course, there are many other programs that can be used as an alignment between SMK and industry.

The importance of preparing graduates and recruiting workers for industry is an advantage that needs to be increased. This is an investment that can be developed and improved so that it is of higher quality (Mahmudah \& Cahya, 2020). Various statements from previous studies confirm that this research is different and has its own charm. This research will reveal the alignment that needs to be made by SMK with industry. The benefits of this research are for developing the capacity of SMK and for preparing the workforce for industry. This becomes more specific if SMK and industry have a harmonious relationship to achieve the same goal even though they have different roles. The novelty of this research is to dig deeper information from activities that must be done together. Based on this, this study aims to determine the alignment of SMK based on industrial needs in this era of very rapid development.

\section{Method}

\section{Research Design}

This research uses qualitative. The purpose of using qualitative is to explain the phenomenon of vocational alignment based on the in-depth schema. This statement is in line with that conveyed by (Creswell, 2014) that qualitative research is an approach for exploring and understanding the meaning individuals of groups ascribe to a social or human problem. The approach used in this research is a case study. This is used to reveal carefully related vocational activities that need to be carried out and developed by the SMK strategies used in the research. This statement is in line with that conveyed by (Yin, 2018) that the use of theory and theoretical propositions in doing case studies can be an immense aid in defining the appropriate research design and data to be collected. Therefore, to reveal the activity-related data of the SMK alignment based on the scheme, the subjects of this study were SMK teachers in various fields of expertise. The purpose of defining this subject is to ensure that the vocational alignment is the same and can be used by all areas of expertise. So that the vocational alignment of this study can benefit all SMK in Indonesia through clear procedures in alignment based on the scheme used according to the area of expertise. 


\section{Data Collection Technique}

The data collection technique used in this study was interviews. Interviews were conducted with vocational teachers who attended the workshop organized by the Directorate of Vocational Education. This interview was conducted to reveal the activities of research subjects that have been carried out in relation to vocational alignment. These activities will then be analyzed. This interview was conducted using structured guidelines. According to (Valenzuela \& Shrivastava, 2018) that interviews are particularly useful for getting the story behind a participant's experiences.

\section{Procedures}

This research procedure uses a case study model (Denzin \& Lincoln, 2018). There are five procedures carried out in this study, namely:

1. Conceptualizing the object of research is done by framing the case and determining the case being studied. This method is done by looking at the phenomenon that occurs in SMK graduates, namely the occurrence of a lot of unemployment. So that this study frames a case that can serve as the right solution for Indonesian vocational education.

2. Determining the research theme by selecting conformity as a research symptom. And develop it by using interviews with research subjects.

3. Creating codes in research, this aims to crystallize relevant study topics so as to reduce participant statements that are not relevant to this research.

4. The validity of the data used in this study is triangulation with a source approach.

5. Presenting several alternative interpretations and formulating a final conclusion statement from the research studies that have been carried out.

\section{Data Analysis}

The analysis carried out in this study used Atlas.ti software version 8.3. The data analysis procedure began with transcribing the recorded interview data. Then input into the software. Next, provide code names in the participant answer data to ensure that the data coded is relevant to this research. The codes that are made become the basis for making the final result or research concept map regarding vocational alignment according to industry needs.

\section{Result and Discussion}

The results of the research that have been obtained are based on in-depth interviews with vocational school teachers in Indonesia, then transcripts are carried out. The purpose of this is to ensure that all answers and statements submitted by participants can be summarized properly without missing a single word. Furthermore, after the transcript is carried out, the researcher performs data reduction to ensure that the data used in the analysis are relevant data with the study topic which is vocational alignment based on industrial needs. The data that has been 
obtained through reduction are then coded to become the basis of the research theme and make conclusions. Based on the work steps that have been submitted, data analysis was then carried out using the Atlas.ti software version 8.3. The results of data analysis can be seen in Figure 2.

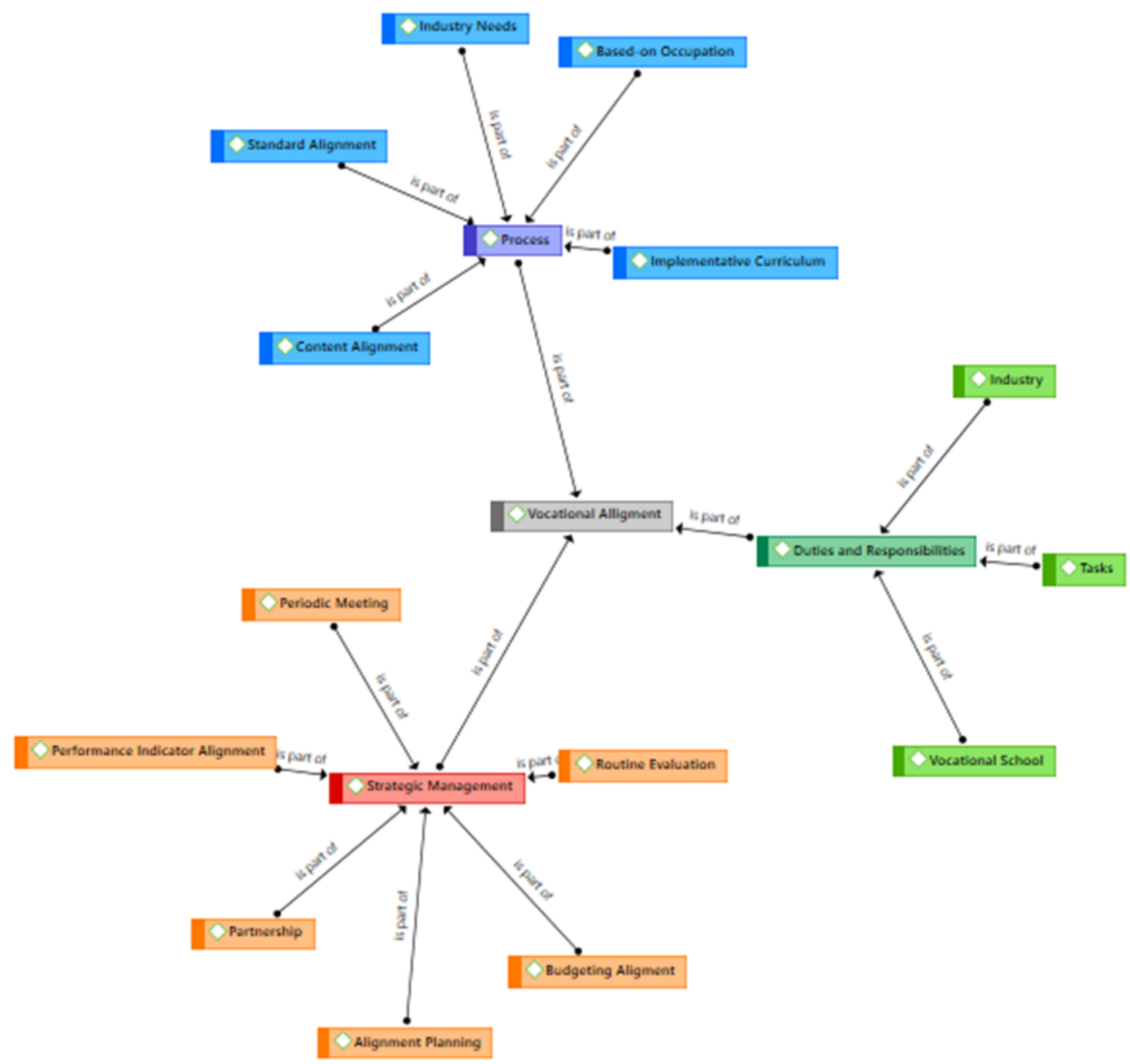

Figure 2. Data Analysis Results of Software Aided Vocational Alignment Research Based on the results of the research shown in Figure 2 above, it can be concluded that research which has the aim of knowing and extracting information related to the alignment of vocational high schools based on industrial needs can be summed up into three main findings, namely process, strategic management, and duties and responsibilities. The three findings from the results of this study provide in-depth information regarding how the alignment between SMK and industry can be carried out. This aims to be able to provide information from the industry about the desired competency needs to vocational high schools which have a role in preparing graduates who have competent competencies and skills as expected by the industry. Therefore this finding is appropriate for SMK and industry in making the alignment. Both parties can understand the roles of one another so as to create harmony in the development of skills and competencies that are expected by the two parties, namely SMK and industry. 


\section{Process}

The process is one of the activities together to determine the same goal. The process in this case is the activity of aligning SMK with industrial needs. The findings of the research show that the process of implementing this alignment has important indicators that need to be considered by two parties, namely SMK and industry, namely content alignment, standard alignment, industry needs, based-on occupation, implementative curriculum. The process developed by both parties is important because it has the same goal of being able to increase skill competency. The findings of this study are in line with those conveyed by (Koppitz, 2013) that recent research states that a teacher's professional identity consists of a cognitive, psychological and also a social perspective. The same thing was also conveyed by (Hausmann, Wirth, Flammer, \& Hofmann, 2020) that a program for the training and further education of trainees, skilled employees medium-sized companies in the personnel transformation process and engineers will be introduced using the example of producing stators with hairpin technology, to support especially small and mediumsized companies in the personnel transformation process. The same thing was also conveyed by (Hargis, 2011) that alignment is critical for business and industry to have access to a trained labor force and critical to students entering the workforce to be able to find jobs.

The process of aligning vocational high schools with industry certainly has steps that must be considered by both parties. The most important thing is the concept of alignment as outlined in the curriculum so that it makes it easier for schools to find out about industry needs. Figure 3 is as stated by (Hargis, 2011) that the alignment process requires a union between the needs of the two institutions, namely schools and industry.

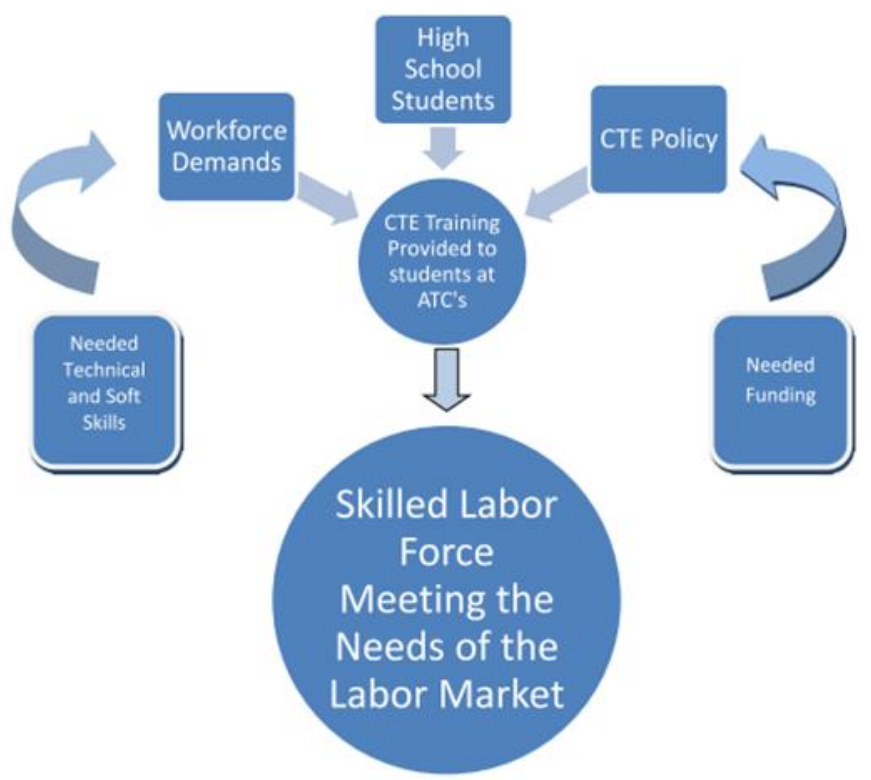

Figure 3. Framework of CTE's Impact on Meeting the Demands of Local Labor Markets Sumber: (Hargis, 2011) 


\section{Strategic Management}

The alignment process will work when it can be combined with management and strategies developed. Of course, schools have different management from management in the industry. Merging these two different things and two different roles requires the right strategy. Based on the findings from the results of this study, the strategic management that needs to be developed by SMK with industry includes alignment planning, periodic meetings, partnerships, budgeting alignment, performance indicator alignment, and routine evaluation. The results of this study are in line with the statement (Yudiono, 2017) from the results of research which states that management of this alignment must be conducted through an institutional establishment in a planned, integrated and sustainable manner by involving stakeholders. The same statement was also made by (Maria, Bianchini, Russo, \& Sergipe, 2018) that strategic alignment can help in understanding the nature and patterns of inter-relationships between the destination and organization marketing domains, recognizing the need for any strategy of considering external and internal environments. Strategic management can be used as a focus in setting goals by SMK and industry (Kurniawan \& Mahmudah, 2020). This can be described as the findings from the research results from planning to evaluation. It will better understand between SMK and Industry, ideally this strategic management is arranged by both parties together. So that a series of activities carried out can be monitored together and can be evaluated together. Therefore, the alignment of SMK will be easier to coordinate and do as well as possible. The end of the strategic management that is used in alignment is to be able to improve the competence of students, graduates, and prospective workers who enter the industry.

\section{Duties and Responsibilities}

Schools have a different role compared to industry. These two different institutions have one goal, namely to provide graduates and prospective workers who are highly competent, able to be competitive, have character, and are able to work under pressure. Each institution has its own obligations. It's just that because this is a vocational alignment, it means that two different institutions will unite and have a responsibility to help each other. On that basis, schools and industry should ideally be able to coordinate and organize all operations related to competency improvement. This is like the analysis of this research, that there are three things related to the duties and responsibilities, 
namely task, industry, and vocational school. The results of this study are as presented by (Mouzakitis, 2010) that the effectiveness of a training system, dependant on a well developed TVET curriculum is measured by (a) the degree of future occupation skills of employees, which employers need, (b) the delivery of courses which will help students to learn how to cope with new challenges and (c) the extent of preparation of learners for life long learning. A similar statement was also conveyed by (Shereni \& Shereni, 2019) that TVET institutions are important players in the hospitality industry in the face of skills mobility across geographical boundaries and if they are to be effective in replacing the sector-specific skills lost to other countries, there is great need to address the challenges they face identified in this study.

\section{Conclusion}

Based on the results of the research and discussion above, it can be concluded that there are three findings that need to be considered by SMK and industry in making alignment, namely with process, strategic management, and duties and responsibilities. Three things that are the findings of this study can be used jointly and continuously between SMK and Industry. It aims to be used as a reference in increasing skill competencies for prospective vocational school graduates and for prospective workers in the industry. The balance between providing competence for students and the readiness of graduates to enter the industry is the right step to provide solutions related to the large number of unemployed people in Indonesia today. Merging two different roles between SMK and industry is an effort that must be continuously developed in line with the increasingly rapid industrial development. Therefore, in this case, industry has a dual role, that is, apart from being profit-oriented, it also helps SMKs to provide skilled, reliable, competent, competitive workers who are able to work under pressure.

\section{ACKNOWLEDGEMENT}

The researchers would like to thank the Directorate of Partnership and Alignment of DU/DI (MITRAS DUDI), Directorate General of Vocational Education, Ministry of Education and Culture for inviting me and participating in the preparation of guidelines used for SMK throughout Indonesia. With this good opportunity, I was able to conduct interviews with SMK teachers throughout Indonesia in the coordination meeting "Alignment of SMK with DU/DI through the Scheme". I would also like to thank the SMK teachers throughout Indonesia for taking the time and answering the questions I asked, amidst my busy schedule compiling skills competencies based on the needs of DU/DI. 


\section{References}

Badan Pusat Statistik (BPS). (2020). Tingkat pengangguran terbuka menurut jenjang pendidikan februari 2019-2020 (p. 1). p. 1. Jakarta.

Creswell, J. W. (2014). Research design: qualitative, quantitative, and mix method (pp. 107-205). pp. 107-205. United Kingdom: SAGE Publications, Inc.

Denzin, N. K., \& Lincoln, Y. S. (2018). The sage handbook of qualitative research fifth edition. United States: SAGE Publications, Inc.

Hargis, K. B. (2011). Career and technical education program alignment with local workforce needs. Eastern Kentucky University, 1(1), 2-160.

Hausmann, L., Wirth, F., Flammer, M. O., \& Hofmann, J. (2020). ScienceDirect ScienceDirect Aligning vocational training to the electromobile transformation Aligning vocational to Factory the electromobile transformation by establishing the training "Training Stator Production" - A by methodical establishing deficit the "Training Stator Production" - A analysis Factory with derivation of measures methodical deficit analysis with derivation $\begin{array}{lllll}\text { of measures. } & \text { Procedia } & \text { Manufacturing, } 45 & \text { (2019), 448-453. }\end{array}$ https://doi.org/10.1016/j.promfg.2020.04.051

Koppitz, T. (2013). Teaching in vocational schools: educational aligment versus the promotion of talents. Journal of Social Science Research, 1(1), 9-13.

Kurniawan, A., \& Mahmudah, F. N. (2020). Implementation of Learning in Vocational School. AlTanzim: Jurnal Manajemen Pendidikan Islam, 4(2), 184-196.

Mahmudah, F. N., \& Cahya, E. (2020). What makes employees productive and have high performance? human capital investment in universities. Asian Journal of Education and Social Studies, 11(1), 21-36. https://doi.org/10.9734/AJESS/2020/v11i130281

Maria, I., Bianchini, E., Russo, S., \& Sergipe, U. F. De. (2018). Strategic alignment: management models and other organizational possibilities. International Journal Fo Innovation Education and Research, 6(6), 2-18. https://doi.org/10.31686/ijier.Vol6.Iss8.1041

Mouzakitis, G. S. (2010). The Role of Vocational Education and Training Curricula in Economic Development. Procedia Social and Behavioral Sciences, 2(2), 3914-3920. https://doi.org/10.1016/j.sbspro.2010.03.616

OECD. (2020a). OECD Reviews of Vocational Education and Training: Skills Beyond School Synthesis Report (United Kin). OECD Publishing.

OECD. (2020b). Skills at work: how skills and their use matter in the labour market. France.

Priambudi, P., Mahmudah, F. N., \& Susatya, E. (2020). Pengelolaan kelas industri di sekolah menengah kejuruan. Jurnal Pendidikan Teknologi Kejuruan, 3(2), 87-97. 
Rahayu, A., Wibowo, L. A., \& Sulastri, S. (2020). Analysis of Link and Match Policies in Improving Work Readiness of Vocational Student in West Java. 3rd Global Conference On Business, Management, and Entrepreneurship (GCBME 2018), 117(Gcbme 2018), 179-181.

Shereni, N. C., \& Shereni, N. C. (2019). The Role of Technical and Vocational Education and Training (TVET) in Restoring Hospitality Sector Specific Skills in Zimbabwe: A Students' Perspective. Journal of Hospitality \& Tourism Education, 0(0), 1-9. https://doi.org/10.1080/10963758.2019.1655434

Tamrin, A. G., Slamet, P., \& Soenarto. (2018). The link and match of the demand and supply for productive vocational school teachers with regard to spectrum of vocational skills inthe perspective of education decentralization. Jurnal Pendidikan Vokasi, 8(1), 40-52.

Valenzuela, D., \& Shrivastava, P. (2018). Interview as a method for qualitative research (pp. 3-20). pp. 3-20.

Yin, R. K. (2018). Case study research and applications design and methods, sixth edition. United Kingdom: SAGE Publications India Pvt. Ltd. B.

Yudiono, H. (2017). The alignment of productive competence on machinery between vocational education institutions and industry. World Transactions on Engineering and Technology Education, 15(3), 256-259 